\title{
Purkinje cell protein-2 regulatory regions and transgene expression in cerebellar compartments
}

\author{
Sylvie Vandaele, ${ }^{1,3}$ Daniel T. Nordquist, ${ }^{2}$ Rodney M. Feddersen, ${ }^{2}$ Irene Tretjakoff, ${ }^{1}$ Alan C. \\ Peterson, ${ }^{1,3}$ and Harry T. Orr ${ }^{2}$ \\ ${ }^{1}$ Ludwig Institute for Cancer Research, Montreal, QC, H3A 1 A1 Canada; ${ }^{2}$ Department of Laboratory Medicine and \\ Pathology and Institute of Human Genetics, University of Minnesota, Minneapolis, Minnesota 55455 USA
}

\begin{abstract}
The Purkinje cell protein 2 (Pcp-2) is expressed in cerebellar Purkinje cells and retinal bipolar neurons. To illuminate how Pcp-2 expression is restricted to only two neuronal types and to derive tools to express heterologous genes in these neuronal subpopulations, genomic sequences of the mouse Pcp-2 gene have been cloned and flanking sequences have been evaluated as a source of neuron-specific regulatory elements. An upstream region with homology to other genes expressed in neurons was identified and a hybrid gene containing this sequence was constructed by ligating $0.4 \mathrm{~kb}$ of upstream and $0.3 \mathrm{~kb}$ of downstream $P c p$-2-flanking DNA to lacZ. Transgenic mice bearing this construct exhibited $\beta$-galactosidase in a wide array of neuron types, suggesting that this sequence may play an important role in specifying neuronal expression. Addition of a further $3.1 \mathrm{~kb}$ of $P c p$-2 upstream sequences restricted expression of $\beta$-galactosidase to a small number of neuron types and most notably to Purkinje cells within parasagitally oriented cerebellar compartments. The presence of elements lying within the $3.1-\mathrm{kb}$ upstream region and acting to specifically restrict $\boldsymbol{P c p}$-2 expression is therefore suggested. Moreover, as $\beta$-galactosidase was not expressed in the bipolar cells of these transgenic mice, retinal expression of the endogenous Pcp-2 gene must involve elements in addition to those conferring expression within Purkinje cells.
\end{abstract}

[Key Words: Pcp-2; transgene; neuron-specific; Purkinje; cerebellar compartments]

Received February 28, 1991; revised version accepted April 17, 1991.

Whereas most regions of the mature nervous system contain numerous intermixed cell types, the cerebellum is relatively simple, being organized into three discrete layers and containing only five principal types of neurons. It is also a region of the brain which, in the mouse, undergoes much of its development after birth and numerous mutants that cause developmental or degenerative cerebellar anomalies have been characterized. Because of these attributes, the cerebellum, and particularly the cerebellar Purkinje cells, have become the object of numerous investigations addressing the mechanisms leading to the developmental specification of neuronal cell type.

Among the genes contributing to the molecular identity of Purkinje cells is Purkinje cell protein 2 (Pcp-2). This gene was identified recently via the cDNA clones PCD5 (Nordquist et al. 1988) and L7 (Oberdick et al. $1988,1990)$ and is noteworthy because $P c p-2$ mRNA and the 99-amino-acid cytoplasmic protein it encodes have been found only within cerebellar Purkinje and retinal bipolar neurons (Nordquist et al. 1988; Oberdick et al. 1988). The Pcp-2 protein becomes detectable in the cer-

\footnotetext{
${ }^{3}$ Corresponding authors.
}

ebellum in the postnatal period (Nordquist et al. 1988; Oberdick et al. 1988) at a time when the Purkinje cell population undergoes its terminal maturation (Miale and Sidman 1961; Altman 1972). Transgenic mice bearing a fusion construct in which $l a c Z$ sequences were inserted within an otherwise intact $P c p-2$ gene were reported to express the anticipated Pcp-2- $\beta$-galactosidase fusion protein in both Purkinje cells and retinal bipolar cells (Oberdick et al. 1990). Thus, significant regulatory elements must lie within the 8-kb fragment of $P c p-2$ genomic sequence involved in the fusion construct. In a further effort to identify the regulatory regions underlying Purkinje and retinal bipolar cell specification and, in particular, to isolate a promoter region that could drive transgene constructs without Pcp-2-coding sequences, we isolated and sequenced a genomic clone containing the mouse $P c p-2$ gene and its flanking sequences. On the basis of the identification of several sequences similar or identical to known regulatory elements within the upstream flanking DNA, we investigated whether different lengths of $P c p$-2-flanking DNA could confer the normal $P c p-2$ expression profile to a lacZ reporter gene in transgenic mice. Elements specifying neuronal expression are located in sequences proximal to the coding sequence, 
and elements restricting expression to Purkinje cells within parasagittally oriented cerebellar compartments, and to superior collicular neurons, lie in $3.1 \mathrm{~kb}$ of upstream flanking DNA. These transgenic mice do not express $\beta$-galactosidase activity in retinal bipolar cells, demonstrating further that additional elements are involved in $P c p-2$ expression in such cells.

\section{Results}

\section{Structure and characterization of the Pcp-2 gene}

A $P c p-2$ cDNA clone was used as a probe to isolate two overlapping genomic fragments from a mouse library (Fig. 1). Sequence analysis of $3.9 \mathrm{~kb}$ of these genomic sequences indicated that the cDNA clone PCD5029 (Nordquist et al. 1988) was contained within a 2 -kb region of genomic DNA in phage $\lambda$ clone 5-111 (Fig. 2). The cDNA sequence is encoded by four exons (bold characters in Fig. 2). Exon 1 and the $5^{\prime}$ half of exon 2 encode the 5 '-untranslated region while protein-coding sequences are distributed among exons 2-4. Exon 4 also includes the 3 '-untranslated region. The predicted splice sites all adhere to the GT and AG dinucleotide motif. A single poly(A) addition signal is located 42 bases downstream from the stop codon.

To position the start site of $P c p-2$ transcription relative to the $5^{\prime}$ end of the cDNA sequence, a 27 -mer oligonucleotide complementary to the $5^{\prime}$ end of the PCD5029 cDNA (Nordquist et al. 1988) was used to prime reverse transcription of cerebellar poly $(\mathrm{A})^{+}$ mRNA. Figure 3 presents the results of this reaction and a sequencing ladder obtained with the same oligonucleotide as a primer. A major band is seen that defines a fragment ending 22 bp upstream from the 27 -mer primer. A minor band representing a primer extension product of 40 nucleotides is also observed. Thus, for the cerebellum, the predominant start site in the $P c p-2$ gene is at adenine 936 of the genomic sequence. A polymerase chain reaction (PCR) using primers corresponding to positions 936-958 and 2812-2833 of the genomic sequence also generated the predicted 480 -bp product from reverse-transcribed cerebellar mRNA (data not presented), demonstrating that the $5^{\prime}$ end of $P c p-2$ mRNA extends into the sequence complementary to the $5^{\prime}$ oligomer and that the intron/exon boundaries have been correctly assigned. RNase protection experiments also confirmed that the major transcription start site was located in the same region indicated by primer extension (data not shown).

Promoter and putative regulatory elements were found in the $5^{\prime}$ DNA flanking the $P c p$-2-coding sequence /Fig. 2). Nucleotide 529 corresponds to the $5^{\prime}$ end of the smaller construct DN5Z03, hereafter referred to as Z03. This construct therefore contains two TATAA elements located at nucleotides 868 (TATAACA) and 898 (TATAAGA), (44 and $32 \mathrm{bp}$ upstream of the minor and major initiation sites, respectively), two inverted repeats of 22 and 14 bp centered at nucleotides 604 and 637, respectively, and sequences sharing homology with certain other genes expressed in neurons. Nucleotides 711726 (corresponding to -225 to -210 from the major start site) share identity with nucleotides located at -995 to $-986(10 / 11)$ from the start site of rat neuronspecific enolase (NSE; Sakimura et al. 1987) and with the peripherin sequence ( -77 to $-64: 11 / 15$; Thompson and Ziff 1989) described by Maue et al. (1990). A CCAGGcontaining sequence (Maue et al. 1990) shares homology with NSE, human neurofilament-M/hNF-M; Myers et al. 1987), rat peripherin, mouse neurofilament-L (mNF-L; Nakahira et al. 1990|, rat type-II Na channel, rat SCG10 (Mori et al. 1990), and Drosophila DOPA decarboxylase (Ddc; Scholnick et al. 1986) genes. Moreover, in the course of this investigation, a general organization for these sequences became apparent; the consensus se-

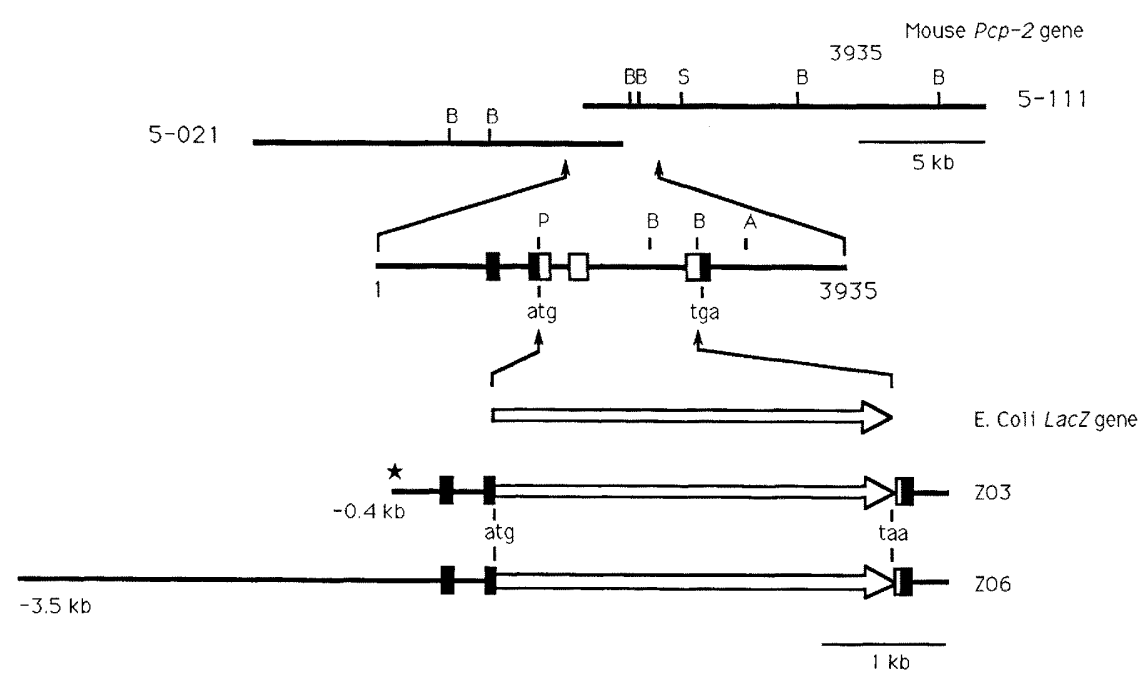

Figure 1. Organization of the $P c p-2$ gene and of the $P c p-2-1 a c Z$ constructs $Z 03$ and $Z 06$. Inserts of two mouse genomic clones 5-021 and 5-111 are depicted with mapped restriction enzyme sites. (B) BamHI; (S) SalI; (P) PvuI; (A) AvaI. The general organization of the sequenced 3935-bp fragment is presented. Boxes indicate exons. (Solid boxes) Noncoding sequences; (open boxes] coding sequences. In both constructs the $P c p$-2-coding sequences and introns, extending from the initiation ATG to the BamHI site in the fourth exon, were replaced with the $E$. coli lacZ gene from pMC1871. The LacZ gene is depicted by a large open arrow and contains a TAA stop codon. Pcp-2 $5^{\prime}$ and $3^{\prime}$ sequences are depicted by a line and solid boxes. The star above Z03 corresponds to nucleotide 529 in Fig. 2. Details of the construction of Z03 and Z06 are presented in Materials and methods. 

ACGAAGACAACTCAAATTGGCATTTGAGGGGCAGATAAACAGGAGCATCCGGTAGTTTCACAGGTGGTCGGGTAGCAGGAGCCGGGTTGGTTGGTTGGTCTGTGGAGAGTGCAGGGATTAAGGGA 250 ATTTGCAT GGGGACTTTCC octamer-11ke B-l1ke

AGAGGCCTGGACCCCAACTTCTTCCTTGGCTACCCCCCTGAAAATGTCACCTGCCTTGCATGGACGAACTCACAGGCAGGAATGGGTTGGCTTGGGTGGGGACATCCTGCAGGTTCCACCCTCAT 375 GGGGACTTTCC B-l1ke

GTTGGTTCATCTTCAACATTGTACTGACTTCTTCCCACTTGACATTCCTCAAGgTCCTGTGATCATGGCTGGGTCTAGTGAGGTTCAAACCTGCACTGCCCTACCCACACCCACACCCAGCTCAG 50O

AP-1-11ke

TCAGTCA (IL 2)

TGAGTCA (consensus)

CACCC bOX

TGAGTCA (consensus) 4

CGTCA

CRE-core

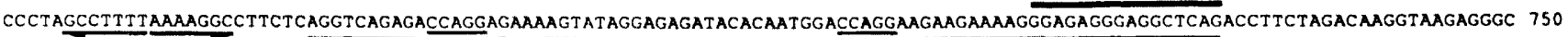
CCAGG containing sequence

TCTGGCTGACTCCACCATCCGCTTCTTGAGGTCTCGGCACCTGTAATTGACAAGATTAATTCATTTATAGGGCATCTAATTAGCAAGCAAGTCTCTGGAGTCCCCTGACCCAGTTACTATAACAC B75 V 7 exó 1

ACAGGGGGTATAGGTAGGAGAGTATAAGAGCCCCTCCTCAGGGCAAATGAATGGATTCTTAGTACTGTCCCCCAAGAGATAGTMGGTACTAGGATTTAGGGCCACTTCTGAGCCCCATTICCCTO 1000 GTAAGTGTCCCAACCCCCCAAATCAACCCAAGCCTGGTCTCAATCTAGGACAGTGGTAGAATGCTGTCCCTAGAGTCAGTACCATGTGAAATTGTGCTGCAGGCAGGGGCCCCAGGCTGGGAGGT 1125 GGGGGTTGGGGGAGTCAGGGCAGGTCAGGGAAGGAGACTCAGGTTTCATTTAGAGAAATTCTGCAGACCCGTGAGGACTATGGTGAGAGCAGAGATGGGAAGGCAGGCACTGTTTCGGGTGGATG 1250

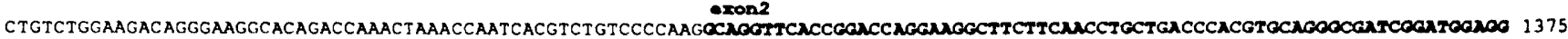
MetGlug

AGCAGCGCTGTTCCTTGCגGOCTOGOCCAOGCCAGNACCCAGNAOCCGTAAGCAGGGCGTGATTGGGCCGTGTGTGTGTGTGTGTGTGTGTGTGTGTGTGTGTGTGTGTGTGGCAGGAGTGCTG 1500

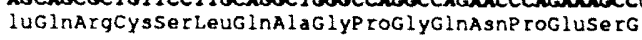

GGGTTCTGGGATCTTGTGGATCTTGGGACTCAGGATGGGGTCTGTATTCATGCCTGCCTGTCTCTGCTCCAAGCAGACGGTGOCCCTOCTCCAGAGATCGACAATCTCATCGATATOCTCOTCAN 1625 InGl YGlyP roAlap roglumet AspasnLeuMet AspMet Leuvalas

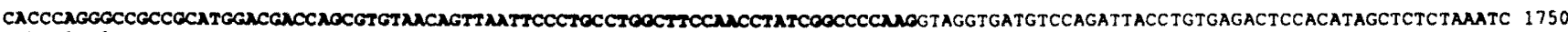
nThrGInGlyArgArgMet AspAspglnArgValThrValAsnSerLeuP roGlypheGinP rol leglyP rolys

TATGACCTGTCTCTAGGCAGGAAAGGAGAGGACCCTATGAACACGTAAAGTGCTATGGGCTTAAGGTCAGGTGGCAGGACTCATGCTAGTGCAGAACTATGGCTGGAAATTACAGTTCCTGCTCC 1875 AACATCTGTATATTTGGGAGAGGCCACAGGGAGAAAACAGGCAGTTTTCCTGGAAGGCATATGAATGCATACCCCTATAAATCAATGAAGAGTAGGGCTTCTGTTTGGGAGTGTTTTGCTTTATT 200O GTTTTTGAGACAGGGTTTCATGTAGCTCTGGCTGGCATGTTCTCCTACATGTGCATCCTGGGTTCTGGGATAACAGGTGTGAGTCACCATGAGTGATGTATGTGGGTAGGGATAGAACCAGGGC 2125 TTTGATGCAGTCTCTATCAACTGAGCTCCAGCCCCAGCCCTATGTCTGTGTACATTAGCATACATGTTTAGAGCTCCGGGCACACGTGTGCACACGCAGGTGGAGGCCAGAAGTCAATCTCCTGC 2250 CCTGGGAGCTTTCAGTGCCCTGGAACTCCAGGTAGATCAGGCTCTCTAGCTAGGAAGCCCTTGGGATCCTCCTGACTCTTAAGCACTGAGATTACAAGTGCATAAACCCACACCTGGCTTAAACT 2375 CAGGTCTTCAAATGAGCATAGCAAGGATTTCAATGACTGAGCTATCTTCTCAACTCAACTGTTTGTTTGTTTGTTTTAGTATITAGCTTTGAACTCAAAATAATCCTCCTGCCTGTTTCTTGAGT 250O ACTGGGATTACAGGTATACACTAACAGGCCAATGTCTGACCAAATACCACCACCCTAATTAGCAGACGAAAAAAAAACATTGTTTGGAGGCACTTCTGACTTGCACTTTCCTTGGTCCCCTCCCT 2625

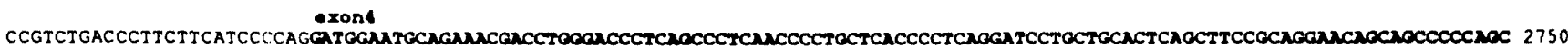

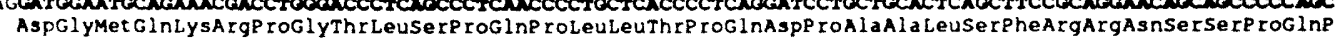

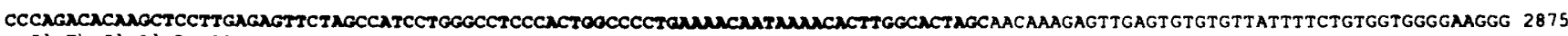
rOGINThIGINAL aP rOTER

AGCTGGGACTTGAGGAACTGAAGGTCTCAGGAGCTCTGCTGGGCAGCTTGAAGAAGTCTCTCTTCTTTCTGCTTCCGGATCTTCTGCTTAAATTCTTCTAGCTCCTGGCGCTGGAATGGGGAAAG 3000 GGGTGTGATGGGAAGGAAGGAAGAGTACAGGCCTCACAGCCTGGACTCACTCACACTATCCTCCCTTTGGCTTCAGAGTTCAGTATCCACACTGGGAGCCCCATGCCAATCACAATCACTGTACA 3125 AGTGAGTTCAGCTTCATCCCTCGGGGAAAAGGTAATATGTGACACCATTTGTGCCCTCCCCTCTTTTTAAGATGGGGTCTCATATACTACAGGCTAGCCTTGAGCTCACCAGGCGGCAGAGAATA 3250 GCCAGAATTCTCAATCCTCTTGCATCCATCTCCTGAGTGCTGGAATGCTGGAATTACAGCTTCCTCTCCTGTCTCCCTCTCTCTATCCCCATGCAGCCCAGGCTAGCTTCAATCTGATACTCCTC 3375 CTACTCCTCCTTCCAAGTGTCCGTAGGTATACACCATCACAAACAACAAGAAACCTTTATGGAGACAAGGTCTCTAGCCCAGGCTAGTCTGGAATTCCTACTCAGTCTGCTGCTTCCACTTTCCT 350O ACCTATGGCTGAGGGTGAAATCTTTATTCCAAGCCCAACTAGGTAAGAGTGACTCAGCTCCTTGGGGAAAACAGGTTACTGACCTGACCCTCCTTCTCTCTTGGCCACAGCTCCCTCTGTGGAAC 3625 AAAGTCACAGGTGAGAACACAAGGCAGGAGAATCCAGAGCCCCACATCCACAACAGGGTTGACTCATGAGAGGCAGACAATGGATCTCAATAGCAAGTTGGTGCTTCATACCCTCCCTTCCGCAG 375O GAATTATCCATCAAGCACTTTGATACCCACCTTACGCTGGACAACATAGTCCTCAAACCACTCAGCCTGATTGGAGATCCAGAACATAACCACGGGGAAAGGAGGTAGAGGGACATCTGTAAAA 3875

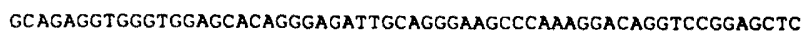

3935

Figure 2. Sequence of the $P_{c p}-2$ gene. Bases depicted as bold letters correspond to the sequence of cDNA PCD5029 (Nordquist et al. 1988). Dyad symmetries are underlined by inverted arrows. TATA boxes and poly(A) addition signal elements are underlined with thin lines. Putative regulatory elements and the region with homology to the sequence between nucleotide -998 and -986 of the rat NSE are underlined in bold; their names and consensus sequences are indicated near the $P c p-2$ sequence. Arrows indicate transcriptional start sites identified by primer extension (the open arrow indicates the weak site; the solid arrow indicates the strong site). The dashed line at $5^{\prime}$ end of exon 1 identifies the 27 -mer oligonucleotide used for primer extension analysis. The star at base 529 indicates the 5 'end of genomic clone 5-111 and of transgene Z03. 


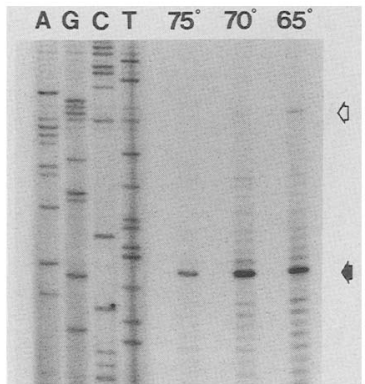

Figure 3. Autoradiogram of $P c p-2$ primer extension analysis of poly- $(\mathrm{A})^{+}$-selected RNA from the cerebellum of a 20 -day postnatal mouse. RNA was annealed at three temperatures $(75,70$, and $\left.65^{\circ} \mathrm{C}\right)$ to the exon 1-specific oligonucleotide. Subsequent extension of the labeled primer generated the major products indicated by the open and solid arrows. The A G C T ladder was generated by dideoxy sequencing 5-021 plasmid DNA using the above primer. The locations of the start sites indicated in Fig. 2 correspond to these extension products.

quence AGCTTG(A/T/G/C)G(C/G/A)CCAGG is followed by an AG-rich region, and the consensus GGA/G/ T)(C/G)CTG is positioned at the end (Fig. 4A).

In the sequences located upstream of nucleotide 529 (Fig. 2) and therefore contained only within the larger DN5Z06 construct (hereafter referred to as Z06), sequences homologous to known elements recognized by transcription factors are found at nucleotide 501 [cAMP response element (CRE); Quinn et al. 1988], at nucleotide 503 (AP-1-binding site; Fujita et al. 1983; Angel et al. 1987), at nucleotides 476 and 482 ( $\beta$-globin consensus; Myers et al. 1986; Locker and Buzard 1990), and included in an inverted repeat, at nucleotide 141 lOct protein-binding site: Sen and Baltimore 1986a; O'Neill et al. 1988, Schöler et al. 1989a,b). Three sequences similar to the B sequence (NF-kB-binding site; Sen and Baltimore 1986a,b) and to B-like sequences in the proenkephalin promoter /Fig. 4B; Rosen et al. 1984; Korner et al. 1989) begin at nucleotides 90,165 , and 348 .

\section{Production of Pcp-2-lacZ transgenic mice}

To locate the region of the $P c p-2$ gene controlling its spatial and temporal expression, transgenic mice bearing $P c p-2-l a c Z$ fusion genes designated Z03 and Z06 were produced (Fig. 1). The Z03 construct was generated by replacing the exon and intron sequences in the $P c p-2$ gene with the coding region of the lac $Z$ gene, encoding bacterial $\beta$-galactosidase. $l a c Z$ is thus flanked on its $5^{\prime}$ end by $1.3 \mathrm{~kb}$ of upstream $P c p-2$ DNA, including $0.4 \mathrm{~kb}$ of $5^{\prime}$-upstream flanking DNA, the untranslated first exon, the first intron and the $5^{\prime}$-untranslated region of exon 2. On its $3^{\prime}$ end it is flanked by $0.124 \mathrm{~kb}$ from exon 4 , including the $P c p-2$ polyadenylation site and $0.3 \mathrm{~kb}$ of Pcp-2 3'-downstream sequences. Z06 had the same structure except that the upstream $P c p-2$ DNA sequence extends for $\sim 3.5 \mathrm{~kb}$.

Four primary $\mathrm{Z} 03$ founders, designated A1, A2, A3, and $\mathrm{A} 19$, and one primary $\mathrm{Z} 06$ founder, designated $\mathrm{B} 2$, were produced. To establish transgenic lines, these founders were bred to either $\mathrm{B} 6 \mathrm{C} 3 \mathrm{~F} 1$ or $\mathrm{B} 6 \mathrm{C} 3 \mathrm{~F} 2$ mice. Founder Al transmitted the transgene to its offspring in an unexpectedly high proportion $(24: 33)$, suggesting multiple insertion sites. Restriction map analysis of tail DNA digested by $\mathrm{Xbal}$ confirmed this hypothesis, and two lines in which the construct was inserted at different sites were established and designated $A 1 \alpha$ and $A 1 \beta$. Similarly, three lines designated A19 $\alpha, A 19 \beta$, and A19X were established from founder 19 . The single $\mathrm{B} 2$ founder had an exceptionally low rate of transgene transmission $(7: 42)$ and therefore was thought to be a mosaic of normal and transgene-bearing cells. Despite this result, offspring of this founder also revealed various restriction patterns in Southern blots of tail DNA digested with $\mathrm{XbaI}$ or $\mathrm{NcoI}$. Three lines, B $2 \alpha, \mathrm{B} 2 \beta$, and $\mathrm{B} 2 \gamma$, in which unique restriction patterns were stably inherited, were derived. Further evidence that these B2-derived lines contain unique loci was obtained by analyzing the offspring derived from a single mouse expressing the combined $\alpha$ and $\gamma$ restriction patterns. Had these two patterns defined alleles at only one locus, a cross with a nontransgenic mouse would have resulted in progeny bearing either the $\alpha$ or $\gamma$ transgene allele. However, consistent with independent assortment of alleles at different loci, individuals bearing neither transgene locus were observed among such offspring. Each B2 subline also contained a different number of transgene copies with approximately eight, two, and four copies present in lines $\alpha, \beta$, and $\gamma$, respectively (data not shown).

\section{Nervous system-restricted expression of Pcp-2-lacZ transgenes in mature mice}

Endogenous Pcp-2 expression has been detected only within cerebellar Purkinje neurons and retinal bipolar neurons (Nordquist et al. 1988; Oberdick et al. 1988). To determine whether the $P c p-2-l a c Z$ hybrid genes are expressed in a pattern similar to that of the endogenous Pcp-2 gene, tissues from mature transgenic mice were examined for $\beta$-galactosidase activity. No activity was observed in non-nervous system tissues or in retinal bipolar neurons of any line. Activity was detected in three of the seven lines bearing the smaller Z03 construct and in all three of the lines bearing the Z06 construct. Purkinje cells labeled in five of these lines and the Purkinje cell population exhibited a striking mosaic pattern of expression in four lines.

\section{Z03 expression occurs in multiple neuronal types}

Among the three lines expressing the Z03 transgene, variable $\beta$-galactosidase labeling was observed in the Purkinje cell population (all labeled in line A1 $\beta$, Fig. 5A; a variable number in line $A 19 \beta$, Fig. $5 D$; none in line A19X, not shown). While the number of stained Purkinje cells varied significantly between individuals in line A19 $\beta$, the compartmentalized staining pattern in lobule $\mathrm{V}$ remained constant. In the remainder of the cerebellum, parasagittal compartments were most obvious in those mice with the greatest number of labeled Purkinje 


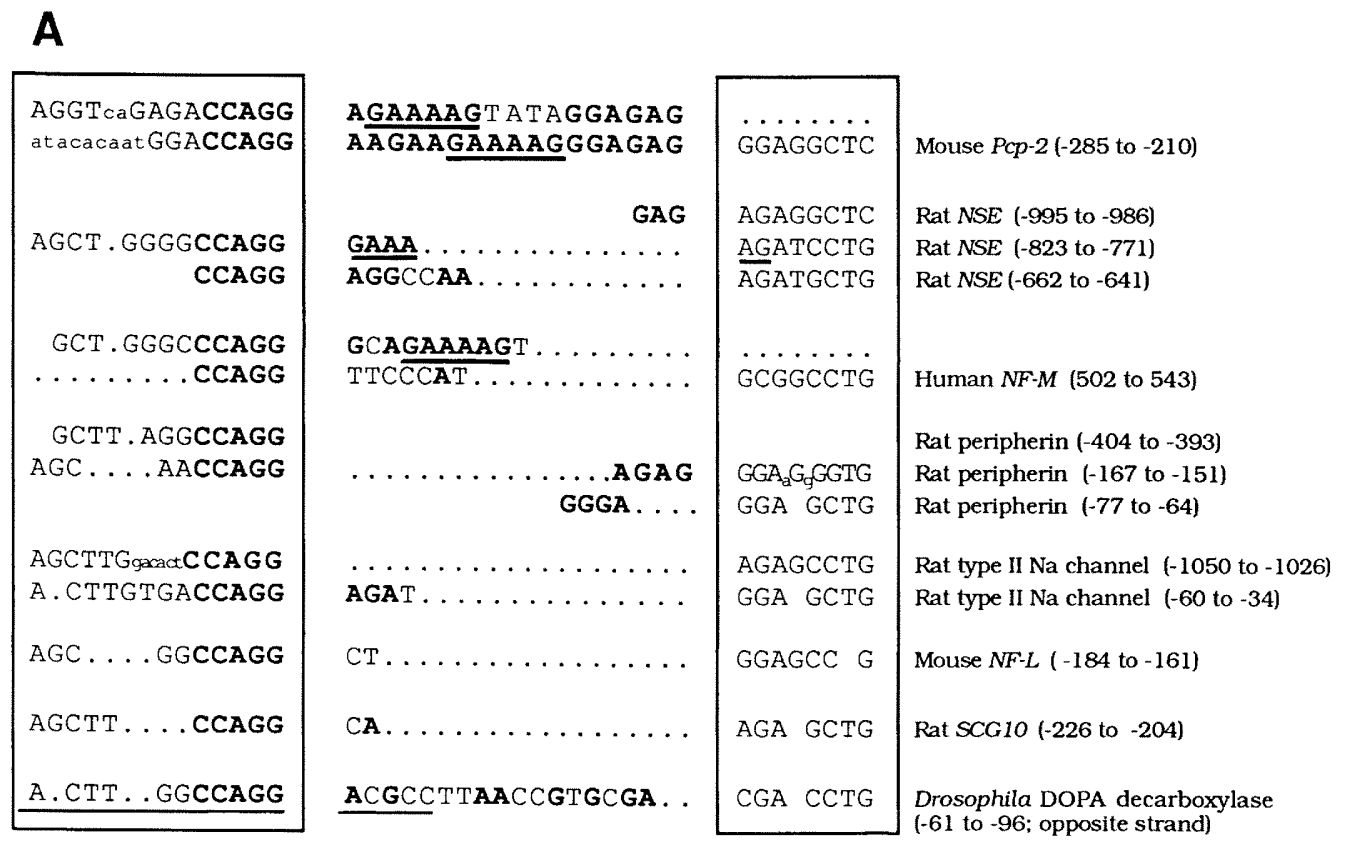

Consensus sequence:

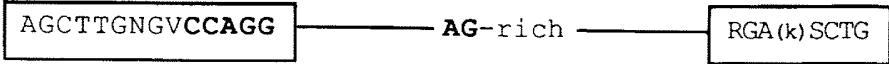

\section{B}

C A G G A G C A T C C G

G G G G A G $C$ C C

\section{$B$ sequence \\ 1 Ptp-2 gene (90 to 100$)$ \\ II Pcp-2 gene (349 to 359) \\ III Proenkephalin enhancer}

(90 bp 5' to the TATA box)

IV Pcp-2 gene (165 to 176)

V Proenkephalin enhancer

(130 bp $5^{\prime}$ to the TATA box) homology with sequences:

$\begin{array}{ll}\text { B } & \text { II } \\ 8 / 11 & 10 / 12 \\ 8 / 11 & \\ 9 / 11 & 9 / 11 \\ & \\ \text { B } & \text { V } \\ 6 / 11 & 9 / 12 \\ 8 / 11 & \end{array}$

Figure 4. 5'-Flanking sequences of the $P c p-2$ gene with homology to genes expressed in the nervous system. $(A)$ The $P c p-2$ sequences lie between nucleotides -285 and -210 from the major initiation site defined by the primer extension experiment /nucleotides 651-726 in Fig. 2). These sequences as well as those for the hNF-M sequences are contiguous, whereas the rat NSE sequences are not, but all contain a GAAAAG sequence (underlined). Except for the SCG10 sequence, parts of the following homologies have been described (Maue et al. 1990): rat peripherin sequences, type-II Na channel sequences, mNF-L, and Drosophila DOPA decarboxylase sequences that contains the element 1 (underlined). The locations of the sequences are from the references cited in Results. Gaps introduced to maximize alignment are indicated by dots. Nucleotide codes: $(N) A, G, C, T ;(R) A, G ;(K) G, T ;(S) C, G ;(V) A, G, C$. (B) Homology between 5' Pcp-2 gene-flanking sequences, the B sequence, and the proenkephalin enhancer (Korner et al. 1989). Nucleotides identical to the $B$ sequence are in boldface type.

cells. In addition, a large number of ectopic, but anatomically definable, sites within the nervous system were $\beta$-galactosidase-positive (line A1 $\beta$, Table 1 and Fig. 5B and F; line A19X, Fig. 5E). At these different sites, the level of $\beta$-galactosidase activity was highly variable. This could represent the density of the cells expressing the transgene, the level of activity per cell, or some combination of the two. However, no obvious relationship was found between the relative level of $\beta$-galactosidase ex- pression in these ectopic sites and that observed within the Purkinje cell population.

During postnatal development, mRNA from the $P c p-2$ gene is first detected in cerebellar samples between day 1 and day 5 (Nordquist et al. 1988), and immunocytochemistry reveals some Purkinje cells positive for the Pcp-2 protein by day 4 (data not shown). In contrast to this normal developmental program, $\beta$-galactosidase activity in line A1 $\beta$ (Table 2) was observed very early during fetal 
development. Distinct staining appeared in the trigeminal ganglia on E9 and in dorsal root ganglia (DRG) on E13. In the cerebellar anlage, staining was first observed on E12. By E18, the cerebellum displayed four prominent rostro-caudal stripes. Although this pattern persisted through P8 (Fig. 5C), all Purkinje cells labeled by maturity (Fig. 5A). However, among the mice of this line, the level of $\beta$-galactosidase activity in Purkinje cells varied. The CA3 layer of the hippocampus expressed $\beta$ galactosidase activity between $\mathrm{P} 1$ and $\mathrm{P} 2$. Outside of the nervous system, labeling was observed only transiently in scattered cells of the lung between E11 and E15 and in the apical ridge of limb buds between E12 and E14.

\section{Z06 expression profile is highly restricted}

In the three Z06 lines, neurons in the deep layer of the superior colliculus and Purkinje cells consistently expressed $\beta$-galactosidase activity (Fig. 5G-N). In all lines, stained Purkinje cells are organized into parasagittal compartments (Fig. $5 \mathrm{H}, \mathrm{K}$, and N). In line B $2 \alpha$, although stained Purkinje cells were found throughout the cerebellum, the density of labeled cells was highest in lobule IX of the vermis (Fig. 5G). In line B2 $\beta$, prominent labeling occurred in lobule IX (Fig. 5N), whereas few Purkinje cells stained in the rest of the cerebellum (Fig. 5M). In line B2 $\gamma$, cerebellar expression was most obvious in the posterior vermis from lobule VI to $X$ (Fig. 5J, and L), in crus I in the hemispheres (Fig. 5J), and in the paraflocculus. Elsewhere, low $\beta$-galactosidase activity was detected in rare cells of the thalamus, cerebral cortex (line B2 $\alpha$ ), pontine, and interpeduncular nuclei and in some DRG (B2 $\alpha$ and $B 2 \beta)$.

$\beta$-Galactosidase histochemistry was performed on each day of development between $\mathrm{E} 8$ and birth in lines B2 $\alpha$ and B2 $\beta$ and up to P6 in lines B2 $\beta$ (Table 2). Lines $B 2 \alpha$ and B2 $\beta$ expressed a similar pattern of $\beta$-galactosidase activity throughout in utero development. Neither line expressed in non-neuronal tissues. In both, transgene expression was first detected on E12 at which time $\beta$-galactosidase activity was expressed in a region of the mesencephalon that appears later to form the deep layers of the superior colliculus (Edwards et al. 1986). By birth, a few stained cells were also observed in the pontine nuclei. In these two locations, the highest staining intensity appeared to occur during early postnatal development. Although unlabeled in mature mice, the spiral ganglia of the cochlea (Fig. 5O) and several apparent ganglionic neurons in the submandibular salivary gland stained intensely on E12, E15, and at birth. DRG were also labeled on E15 and at birth, although at a low level. At birth in both $B 2 \alpha$ and $B 2 \beta$ mice, the cerebellum revealed parasagitally organized compartments of $\beta$-galactosidase activity, and by P6, B2 $\beta$ mice expressed the mature pattern in which $\beta$-galactosidase is expressed exclusively in lobule IX.

\section{Discussion}

Toward the identification of the DNA elements leading to neuronal-type specification, we cloned and sequenced the $P c p-2$ gene. We examined $P c p-2$-flanking sequences for the presence of possible regulatory elements and constructed transgenic mice in which a lacZ reporter gene was ligated to different lengths of $P c p$-2-flanking sequences. The expression patterns observed within these transgenic lines highlights the possible role played by different $P c p$-2-associated sequences.

\section{Z03 contains neuron-specific regulatory elements}

The spatial and temporal variability observed among the three Z03-expressing lines requires that the expression profile of this construct can be influenced by its insertion site (e.g., Swanson et al. 1985; Metcalf and Moore 1988 ; Bonnerot et al. 1990). In line A1 $\beta$, the expression of $\beta$-galactosidase both in non-nervous system tissues during embryogenesis and in neurons is reminiscent of the expression profile of certain transcription factors (He et al. 1989; Suzuki et al. 1990). Also in the A1 $\beta$ line, staining in trigeminal ganglia occurs as early as E9, corresponding to the time at which neurons first become discernible at this site (Davies and Lumsden 1984). DRG begin to label on P13 when sensory neurons are clearly recognizable (Barber and Vaughn 1986); and in the cerebellum anlage, staining occurs at E12 when the first postmitotic Purkinje cells are born (Miale and Sidman 1961). The existence of a transcriptional regulatory mechanism that becomes active at or near the time when neurons become postmitotic is therefore suggested.

Two of the three lines expressed $\beta$-galactosidase in Purkinje cells, suggesting that Z03 contains elements recognized by trans-acting factors present in Purkinje cells. The failure to detect transgene expression in line A19X Purkinje cells while it is expressed elsewhere might involve an exceptional influence of the $\mathrm{X}$ chromosome insertion site (e.g., Covarrubias et al. 1987; Mahon et al. 1988; Al-Shawi et al. 1990). The restriction of Z03 expression to the nervous system of mature mice in all three expressing lines suggests that this construct contains significant neuron-specific regulatory sequences.

The sequenced region of the $P c p-2$ gene does not contain the putative neuron-specific control element GCCCAGCC found in the cap-exon I regions of genes coding for several neuron-associated proteins /Habener et al. 1989). However, a CCAGG-containing sequence located in the upstream flanking regions of other neuron-specific genes (Maue et al. 1990) was found in Pcp-2 at nucleotide 651 and is therefore included in the Z03 construct. This sequence is also found in further constructs expressed in a neuron-specific manner in transgenic mice, including those derived from rat NSE (Fjorss-Petter et al. 1990), hNF-L (Julien et al. 1987), and mNF-L genes (Byrne and Ruddle 1989) and in a neuron-specific enhancer-containing region of the SCG10 gene (Wuenschell et al. 1990). Similarly, this sequence is contained within further constructs expressed in neuronal cell lines, including those derived from the mNF-L (Nakahira et al. 1990) and the rat type-II Na channel genes (Maue et al. 1990). In addition, element 1, the homologous Drosophila sequence 


\section{Vandaele et al.}

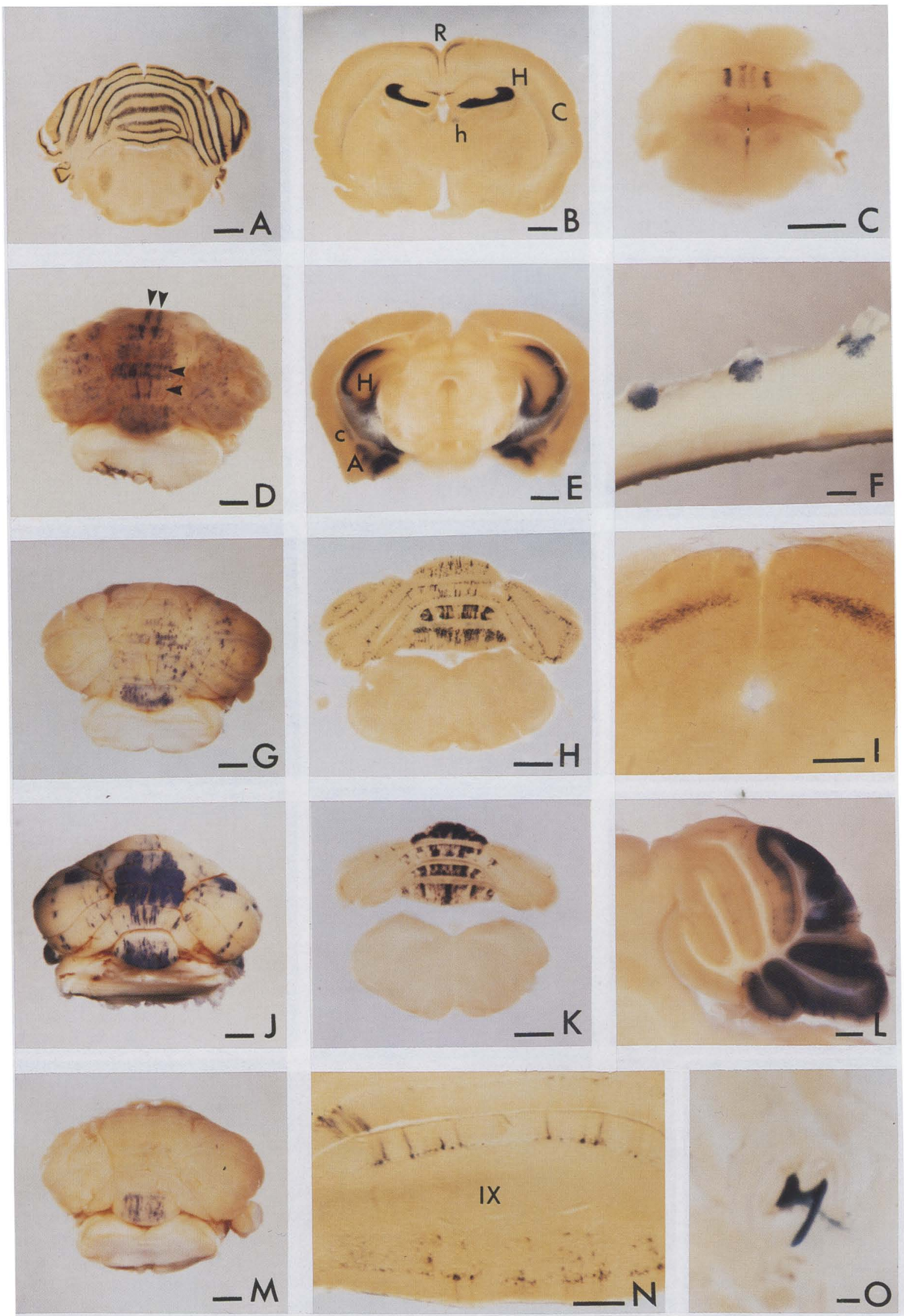

Figure 5. (See facing page for legend.) 
associated with the $D d c$ gene, has been suggested to be necessary but not sufficient for expression in the Drosophila nervous system (Scholnick et al. 1986; Johnson et al. 1989).

In both the NSE and the type-II Na channel genes, several CCAGG-containing sequences are separated by relatively long sequences with no remarkable characteristics. For both the $P c p-2$ gene and the hNF-M genes, the CCAGG-GA-rich sequence motif is repeated once; and in $P c p-2$, the two GA-rich regions show a high internal homology (13/17). The GAAAAG sequence is found twice in the $P c p-2$ sequence but only once in the NSE and the hNF-M genes. Such sequence variation could therefore be relevant to the particular patterns of expression realized by these genes.

\section{Regulatory elements in the Z06 construct}

No line obtained with either the Z03 or Z06 construct expressed $\beta$-galactosidase at a readily detectable level in the retina. Consistent with a model in which different factors in different tissues regulate single genes (for review, see Maniatis et al. 1987), Pcp-2 expression in Purkinje and bipolar neurons must involve different cis-acting elements. Transgenic mice bearing a fusion construct in which lacZ sequences were inserted within an otherwise intact $P c p-2$ gene were reported to express the Pcp-2- $\beta$-galactosidase fusion protein in both Purkinje cells and retinal bipolar cells (Oberdick et al. 1990). The elements contributing to $P c p-2$ expression in the retina must therefore be located in sequences present in the $\mathrm{Pcp}-2-\beta$-galactosidase construct and not included in Z06 (i.e., either in a $0.5-\mathrm{kb}$ sequence, $4 \mathrm{~kb} 5^{\prime}$ of the start site; in the genomic sequence, including exons $2-4$ and the corresponding introns; or in $1.7 \mathrm{~kb}$ of $3^{\prime}$-flanking DNA, beginning $0.3 \mathrm{~kb} 3^{\prime}$ of the polyadenylation site). Constructs designed to locate such elements are presently under investigation.

While the Z03 construct was expressed in a wide array of neuronal types, Z06 expression was consistently detected within Purkinje cells and in the deep layers of the superior colliculus. During development, the cochlear spiral ganglia and a few ganglion-like cells in the submandibular salivary gland also labeled in at least two of these three lines. The similarity of the more restricted expression pattern observed for the Z06-bearing lines suggests that additional elements controlling the temporal and spatial expression of $P c p-2$ are located in $3.1 \mathrm{~kb}$ of sequences upstream of the Z03 construct. However, as Pcp-2 expression has not been observed other than in
Purkinje and bipolar neurons, additional regulatory elements acting to restrict $P c p-2$ expression appear to be missing from the Z06 construct. These could be located either in sequences farther upstream or downstream or in the deleted introns and exons. However, apparently ectopic expression of the Pcp-2- $\beta$-galactosidase fusion protein was also noted by Oberdick et al. (1990); and as no intron or exon sequences of the Pcp-2 gene were deleted in that construct, any further elements regulating the $P c p-2$ gene are likely located in flanking sequences. Alternatively, Pcp-2 may be expressed at previously undetected levels in such additional sites.

Silencers (Brand et al. 1985) have been reported to restrict expression of the rat brain type-II $\mathrm{Na}$ channel gene (Maue et al. 1990) and the SCG10 gene (Mori et al. 1990; Wuenschell et al. 1990); therefore, specific repression has been suggested to be an important control mechanism governing the pattern of gene expression in the nervous system (Maue et al. 1990). Although the sequenced region of the $P_{c p}-2$ gene does not contain known silencer elements (Laimins et al. 1986; Nir et al. 1986; Baniahmad et al. 1987, 1990; Bouvagnet et al. 1987; Imler et al. 1987; Kuhl et al. 1987; Osborne et al. 1988; Berg et al. 1989; Burt et al. 1989; Cao et al. 1989; Emerson et al. 1989; Herbst et al. 1989; Winoto and Baltimore 1989; Ayer and Benyajati 1990; Farrell et al. 1990; Mathey-Prevot et al. 1990; Salier et al. 1990; Savagner et al. 1990), such elements could be specific to the $P c p-2$ gene and/or be located in the flanking DNA not yet sequenced.

Several putative regulatory elements were observed in the sequence upstream of nucleotide 529 and were therefore contained only in the Z06 transgene. These sequences may bind transcription factors expressed in the nervous system and, hence, could contribute to the $P c p$ 2 expression pattern. Transcripts corresponding to the Oct family proteins known to bind octamer elements (Baumruker et al. 1988) analogous to the one found at nucleotide 141 have been found in the nervous system (He et al. 1989; Suzuki et al. 1990). Three sequences are homologous to the $B$ sequence recognized by the transacting factor NF- $\mathrm{KB}$ present in B lymphocytes (Sen and Baltimore 1986a,b) and also by a brain-specific protein, BETA (Korner et al. 1989). Moreover, these Pcp-2 B-like sequences show greater homology with proenkephalin sequences claimed to interact with the BETA protein (Korner et al. 1989) than with the B sequence itself. The CGTCA core characteristic of CREs and found in other neuron-specific genes (Hyman et al. 1988) is located at nucleotide 437 . The putative AP-1-binding site, which

Figure 5. Histochemical detection of $\beta$-galactosidase in the nervous system of transgenic mice. Mice were anesthesized and perfused, and the brain was either kept intact or cut into 100 - to 200 - $\mu \mathrm{m}$-thick sections using a vibratome. $(A-F)$ Small transgene Z03. Line Al $\beta$ $(A, B, C, F)$. $(A)$ Frontal section of mature cerebellum. $(B)$ Frontal section of mature brain in the hippocampal area. (H) hippocampus; $(\mathrm{h})$ habenula; $(C)$ cortex; $(\mathrm{R})$ retrosplenial cortex. $(C)$ Frontal section of cerebellum at P3. $(F)$ Spinal cord with stained DRG. $(D)$ Whole cerebellum of line A19 3 . (E) Frontal section of mature brain in the hippocampal area in line A19X. (c) claustrum; $(A)$ amygdala. $(G-O)$ large transgene Z06. Whole cerebellum $(G, I, M)$ and frontal section of cerebellum $(H, K, N)$ of line B2 $\alpha, \mathrm{B} 2 \gamma, \mathrm{B} 2 \beta$ respectively. $(I)$ Deep

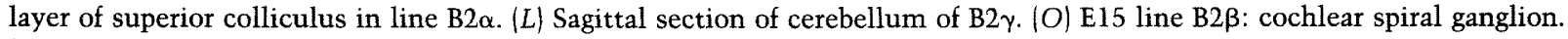

$(A, B, D, E, G, H, I, K, M)$ Bar, $1 \mathrm{~mm}$. $(C, F, I, L, N)$ Bar, $0.5 \mathrm{~mm}$. (O) Bar, $0.1 \mathrm{~mm}$. 
Table 1. Spatial distribution of $\beta$-galactosidase staining in the nervous system of mature mice bearing the $Z 03(A)$ and Z06 (B) constructs

\begin{tabular}{|c|c|c|c|}
\hline Line & $\begin{array}{c}\text { Copy } \\
\text { number }\end{array}$ & $\begin{array}{c}\text { Purkinje } \\
\text { cells labeling }\end{array}$ & Ectopic sites \\
\hline$A 1 \beta$ & $>15$ & all & numerous $^{a}$ \\
\hline$A 19 \beta$ & 8 & $\begin{array}{l}\text { compartmental, } \\
\text { mosaic, variable } \\
\text { among mice }\end{array}$ & none \\
\hline A19X & 12 & none & $\begin{array}{l}\text { amygdala, } \\
\text { hippocampus CA3 } \\
\text { claustrum }^{\mathrm{b}}\end{array}$ \\
\hline $\mathrm{B} 2 \alpha$ & 8 & $\begin{array}{l}\text { compartmental, } \\
\text { mosaic }\end{array}$ & $\begin{array}{l}\text { s. colliculus }{ }^{\text {b }} \\
\text { (pontine nuclei, } \\
\text { thalamus, } \\
\text { interpeduncular } \\
\text { nuclei, cortex, } \\
\text { DRG }^{\mathrm{c}}\end{array}$ \\
\hline $\mathrm{B} 2 \beta$ & 2 & $\begin{array}{l}\text { compartmental, } \\
\text { mosaic, primarily } \\
\text { in lobule IX }\end{array}$ & $\begin{array}{l}\text { s. } \text { colliculus }^{\mathrm{b}} \\
\text { (pontine nuclei, } \\
\text { DRG, } \\
\text { interpeduncular } \\
\text { nuclei|c }^{\mathrm{c}}\end{array}$ \\
\hline $\mathrm{B} 2 \gamma$ & 4 & $\begin{array}{l}\text { compartmental, } \\
\text { primarily in } \\
\text { posterior vermis, } \\
\text { CrusI and } \\
\text { paraflocculus }\end{array}$ & s. colliculus ${ }^{b}$ \\
\hline
\end{tabular}

${ }^{\text {a }}$ Central nervous system) Telencephalon: lamina glomerulosa bulbi olfactori, $\mathbf{n}$. olfactorius $\mathrm{n}$. tractus diagonalis Brocae, ependymal cells (third ventricle); hippocampus: CA3-CA4 layer, presubiculum, subiculum, cortex area cingula, area frontalis cortex cerebri, cortex retrosplenialis; cortex: layer II, III, VI, claustrum, $\mathbf{n}$. caudatus/putamen, globus pallidus, substantia innominata, n. lateralis septi, area amygdaloidea. Diencephalon: habenula, $\mathrm{n}$. medialis dorsalis thalami, $\mathrm{n}$. posterior thalami, n. suprageniculatus thalami, area lateralis hypothalalami, $\mathrm{n}$. ventromedialis hypothalami, $\mathrm{n}$. dorsomedialis hypothalami, zona incerta, corpus geniculatum laterale. Mesencephalon: $\mathbf{n}$. accessorius (Darkschewitz), substantia grisea periventricularis, n. oculomotorii, $n$. interstitiales commissurae posterioris, n. ruber, $\mathbf{n}$. interpedoncularis, fasciculus longitudinalis dorsalis. Pons/Medulla oblongata: lemniscus medialis, raphe dorsalis, raphe centralis superior, reticular formation, $n$. principalis $V, n$. motoris $\mathrm{V}$, superior olive, $\mathrm{n}$. parabrachialis, locus coerulei, $\mathrm{n}$. pontis, $n$. abducens, $n$. medialis, interpositus, lateralis cerebelli, $\mathrm{n}$. facialis, n. cochlearis dorsalis et ventralis, n. paragigantocellularis, $\mathbf{n}$. vestibularis, $\mathrm{n}$. ambiguus. Spinal cord: motor neurons. (Peripheral nervous system) Cranial sensory ganglia, DRG. ${ }^{b}$ Most neurons in these regions express $\beta$-galactosidase.

'In these regions, rare $\beta$-galactosidase-expressing cells were found. Mice were anesthesized and perfused. The brain was recovered, cut into 1-mm-thick sections, postfixed, and stained as described. After the staining reaction, these sections were resectioned at $30 \mu \mathrm{m}$ with a freezing microtome. Sections were mounted on gelatinized slides and counterstained with pyronin Y. Neuroanatomical designations were according to Sidman et al. (1971), and Slotnick and Leonard (1975).

could mediate $P c p-2$ gene regulation through the immediate early genes (for review, see Sheng and Greenberg 1990), overlaps this core, demonstrating the same orga- nization as that observed in the neurotensin/neuromedin N gene (Kislaukis and Dobner 1990).

\section{Transgene expression in cerebellar compartments}

An unexpected feature displayed by all transgenic lines was the striking compartmentalization of $\beta$-galactosidase-expressing Purkinje cells.

An anterior/posterior boundary was observed in line B2 $\gamma$, where only the posterior cerebellum displays a high level of $\beta$-galactosidase activity. This boundary appears to coincide with that found in several mutants in which the anterior and posterior lobes are differentially affected (Leaner, Herrup and Wilczynsky 1982; Meander tail, Ross et al. 1990). As only the B2y line shows such an organization, a region-specific enhancer specifying rostro-caudal compartments near the insertion site could be involved (Tuggle et al. 1990).

In line $A 1 \beta$, the parasagittal organization of $\beta$-galactosidase expression observed in young animals disappears with maturity following the general developmental pattern observed for certain biochemical markers (Wassef et al. 1985). However, the parasagittal compartments observed in all B2-derived lines and in line A19 $\beta$ persist in mature mice, reflecting stable cerebellar organization. Other markers (e.g., Zebrin I and II; Brochu et al. 1990), as well as afferent and efferent projections (Gravel et al. 1987; Boegman et al. 1988), delineate cerebellar compartments. However, in contrast to the Purkinje cell populations expressing such endogenous genes, not all cells within each compartment express $\beta$-galactosidase in transgenic mice. Transgene loci with variable and mosaic expression phenotypes have been observed previously (McGowan et al. 1989); such a circumstance could explain why the lacZ-expressing compartments in line $\mathrm{B} 2 \alpha$ are not obvious in the anterior region of the cerebellum where Zebrin I and II compartments become less discrete (Eisenman and Hawkes 1989; Brochu et al. 1990) and also why a variable number of Purkinje cells express $\beta$-galactosidase in different animals in line $A 19 \beta$.

The mechanisms leading to the compartmentalized organization of the cerebellum are unknown. An anatomical basis for such an organization could originate in the pattern of afferent innervation; however, at least for Zebrin I, compartments can develop in the absence of normal innervation (Leclerc et al. 1988; Wassef et al. 1990). In this case, it seems unlikely that a mechanism affecting either the stability or enzymatic activity of $\beta$-galactosidase itself is involved; $1 a c Z$ expression driven by the NSE promoter does not show such a compartmentalized phenotype (Fjorss-Petter et al. 1990). A role for message stability and/or translational efficiency also appears unlikely; different expression patterns were observed in the Z03 and Z06 lines despite the fact that identical transcripts should be derived from both constructs. It is therefore probable that transcriptional regulatory elements of the $P c p-2$ gene are directly involved in generating such patterns, and further $P c p-2$ constructs should serve to both confirm this hypothesis and locate the relevant elements. 
Table 2. $\beta$-Galactosidase expression in Z03- and Z06-bearing transgenic lines during development

\begin{tabular}{|c|c|c|c|c|c|c|c|c|c|c|c|c|c|c|c|}
\hline Line & Sites & $\mathrm{E} 8$ & E9 & E10 & E11 & E12 & E13 & E14 & E15 & E18 & $\mathrm{P} 1$ & P2 & $\mathrm{p} 4$ & P6 & P8 \\
\hline \multirow[t]{7}{*}{$A 1 \beta$} & cerebellum & & & & & + & + & + & + & + & + & + & + & + & + \\
\hline & DRG & & & & & & + & + & + & + & + & + & + & + & + \\
\hline & ganglion $\mathrm{V}$ & & + & + & + & + & + & + & + & + & + & + & + & + & + \\
\hline & hippocampus & & & & & & & & & & & + & + & + & + \\
\hline & limb buds & & & & & + & + & + & + & & & & & & \\
\hline & lungs & & & & + & + & + & + & + & & & & & & \\
\hline & & & & $n$ & $n$ & & $n$ & $n$ & & $n$ & & $n$ & & & $n$ \\
\hline \multirow[t]{6}{*}{$\mathrm{B} 2 \alpha$ and $\mathrm{B} 2 \beta$} & cerebellum & & & & & & & & & & + & & + & + & \\
\hline & superior colliculus & & & & & + & & & + & & + & & + & + & \\
\hline & pontine nuclei & & & & & & & & & & + & & + & + & \\
\hline & $\mathrm{DRG}^{\mathrm{a}}$ & & & & & & & & + & & + & & + & + & \\
\hline & cochlear spiral ganglia ${ }^{\mathrm{b}}$ & & & & & + & & & + & & + & & + & $\mathbf{n}$ & \\
\hline & submandibular gland ${ }^{b}$ & & & & & + & & & + & & + & & + & $\mathrm{n}$ & \\
\hline
\end{tabular}

Ages not examined are indicated by $n$. Anatomical designations were according to Theiler (1972).

${ }^{a}$ Compared to line Al $\beta$, the DRG in lines $B 2 \alpha$ and $B 2 \beta$ were lightly stained. Only a few DRG neurons stained in mature mice.

${ }^{\mathrm{b}}$ These regions were not stained in mature mice.

In this investigation we have identified several putative regulatory elements in the upstream flanking region of the Pcp-2 gene. On the basis of the expression pattern of $\beta$-galactosidase driven by different lengths of $P c p-2$ upstream sequences, we conclude that elements proximal to the promoter contribute to a neuron-specific expression pattern while more distal sequences act to target high-level transgene expression to only Purkinje cells and neurons of the superior colliculus. Included within the sequences examined are regulatory elements involved in the compartmentalization of the cerebellar cortex. These results support a hypothesis in which specification of gene expression within a neuronal subtype may be achieved through positive pan-neuronal regulatory sequences with such activity restricted by further upstream elements. The absence of expression $\beta$-galactosidase in bipolar cells also suggests that additional elements are involved in the regulation of the $P c p-2$ gene within the retina. Finally, we demonstrate here that $P c p$ 2-flanking sequences can be used to direct the expression of a heterologous gene to restricted subpopulations of neurons.

\section{Materials and methods}

Isolation of the Pcp-2 gene

A genomic library prepared from BALB/c mouse liver DNA (Clontech, EMBL-3) was screened with the cDNA clone PCD5029. Two clones containing overlapping genomic sequences spanning $29 \mathrm{~kb}$ were obtained and designated 5-111 and 5-021. Clone 5-021 included $13 \mathrm{~kb}$ of DNA flanking the $5^{\prime}$ end of $P c p-2$, exons 1,2 , and 3 , and the $5^{\prime}$ half of intron 4 . Clone $5-111$ began $\sim 500$ bp upstream of the first exon in $P c p-2$ and extended to a point $\sim 13 \mathrm{~kb} \mathrm{3}$ ' of exon 4 . The integrity of DNA within these clones was confirmed by comparison of their restriction maps with Southern blot data of mouse DNA /data not shown).

The 5.2-kb BamHI-Sall fragment from 5-021 and the 4.2-kb SalI fragment from 5-111 were subcloned into pUC119 and designated pPN5021a and pPN511la, respectively. A total of 3935 bp of genomic sequence was determined from these subclones beginning at a point 957 bp upstream from the start of PCD5029 cDNA (Nordquist et al. 1988) and extending 993 bp beyond the poly(A) addition signal using the dideoxy method (Sanger et al. 1977). Exon/intron boundaries were assigned by comparison of the genomic sequence with the previously determined Pcp-2 cDNA sequence (Nordquist et al. 1988).

\section{Primer extension assay}

Ten picomoles of ${ }^{32} \mathrm{P}$-labeled oligonucleotide (27-mer: $5^{\prime}$ AGAAGTGCCCCTAAATCCTAGTACCTA-3'; Northern Biosciences/ complementary to the $5^{\prime}$-most sequence of the previously reported PCD5 cDNA (Nordquist et al. 1988) was coprecipitated with $2.5 \mu \mathrm{g}$ of $\mathrm{C} 57 \mathrm{Bl} / 6 \mathrm{~J}$ mouse cerebellar poly $(\mathrm{A})^{+}$ RNA. The pellet was resuspended in $20 \mu \mathrm{l}$ of annealing buffer ( $10 \mathrm{~mm}$ Tris- $\mathrm{Cl}$ at $\mathrm{pH} 8.0,20 \mathrm{~mm} \mathrm{KCl}, 1 \mathrm{~mm}$ EDTA) and incubated at 75,70 , or $65^{\circ} \mathrm{C}$ for $2 \mathrm{hr}$. Moloney murine leukemia virus reverse transcriptase (400 units) and RNasin (40 units) in $50 \mu \mathrm{l}$ of buffer containing $14 \mathrm{mM}$ Tris- $\mathrm{Cl}(\mathrm{pH} 8.3), 14 \mathrm{mM} \mathrm{MgCl}_{2}, 7$ $\mathrm{mM}$ DTT, and $280 \mathrm{mM}$ dNTP were added and incubated for $1 \mathrm{hr}$ at $37^{\circ} \mathrm{C}$. The reaction mixture was ethanol-precipitated and resuspended in $100 \mu \mathrm{l}$ of $80 \%$ formamide loading buffer. A $600-\mathrm{bp}$ genomic fragment (Sau3AI-PstI), including the entire $P c p-2$ exon 1 and $>400 \mathrm{bp}$ of upstream $5^{\prime}$ sequence, was sequenced as described (standard double-stranded technique, Promega) using Sequenase (T7 DNA polymerase, U.S. Biochemical) and the 27mer oligomer described previously. Two microliters of each sequencing reaction $(20 \%)$ and $1 \mu \mathrm{l}$ of the primer extension reaction $(1 \%)$ were resolved on an $8 \mathrm{M}$ urea $/ 8 \%$ polyacrylamide gel (Maniatis et al. 1982). The dried gel was exposed to XAR film (Kodak) for $24 \mathrm{hr}$.

\section{Construction of the Pcp-2-lacZ fusion gene}

Plasmid vector pUC119 (Vieira and Messing 1982) was modified as follows to build vector pDN119NZ: A 165-bp HaeII-EcoRI fragment containing the $l a c Z^{\prime}$ gene was deleted and replaced by a $3.0-\mathrm{kb}$ BamHI fragment from pMC1871 (Pharmacia). The vector containing the lac $Z$-coding sequence oriented in the former $l a c Z^{\prime}$ orientation; an in-frame ATG codon was added to the lacZ gene by replacing the $5^{\prime}$ BamHI site with a $N c o$ linker. A construct was derived from vector $\mathrm{pDN} 119 \mathrm{NZ}$ by the insertion of the two fragments, the first being the $P c p-2$ polyadenylation 
signal (438-bp BamHI-AvaI fragment) and the second containing 5'-flanking and untranslated DNA from genomic clone 5111 (837-bp SalI-Pvul fragment). The PvuI site defining the end of the 5'-untranslated region was ligated to the $\mathrm{Ncol}$ site of pDN1 19NZ with an oligonucleotide that generated a consensus sequence for translation initiation (Kozak 1984). All predicted junction sequences were verified by DNA sequencing.

Construct Z06 was derived from Z03 by ligation of a 3.3-kb $X b a I$ fragment from the genomic subclone PN5021a into the 5 -flanking region of $\mathrm{Z} 03$, followed by deletion of a duplicated 200 -bp SalI-XbaI fragment from the $5^{\prime}$ end of the intermediate construct.

\section{Production of transgenic mice}

Transgenic mice were generated by microinjection of linear DNA fragments into the male pronucleus of $\mathrm{B} 6 \mathrm{C} 3 \mathrm{~F} 2$ zygotes. Transgene-bearing mice were subsequently identified by DNA analysis of tail biopsies (for review of techniques, see Hogan et al. 1986), and Southern analysis of XbaI- or NcoI-digested genomic DNA was performed using nylon membrane (Micron Separation, Inc.) and $\mathrm{a}^{32} \mathrm{P}$-labeled 3 -kb fragment of the lacZ gene as a probe. To determine the number of transgene copies, genomic DNA and lacZ-containing plasmid as a standard were immobilized on nitrocellulose (Minifold II, Schleicher \& Schuell) and hybridized with a ${ }^{32} \mathrm{P}$-labeled lac $Z$ probe. The resulting autoradiogram was scanned on a LKB densitometer.

\section{Detection of $\beta$-galactosidase activity}

Mice were anesthetized with avertin intraperitoneally and perfused transcardially with $0.5 \%$ paraformaldehyde $/ 2.5 \%$ glutaraldehyde in $0.1 \mathrm{M}$ phosphate buffer $(\mathrm{pH} 7.4)$. Spinal cord, inner ear capsules, eyes, and samples of skin, heart, thymus, lung, muscle, liver, spleen, small intestine, kidney, adrenals, and ovaries or testis were recovered and postfixed for an additional 45 $\mathrm{min}$. The brain was cut into $1-\mathrm{mm}$-thick sections using a rodent brain matrix (Activational Systems, Inc.), or into 100- to $200-\mu \mathrm{m}$ sections using a vibratome (Micro-Cut H1200, EM Corp.) and similarly postfixed. In some cases, the cerebellum was processed intact. The samples were rinsed in $0.1 \mathrm{M}$ phosphate buffer $(\mathrm{pH} 7.4)$ and incubated overnight at $37^{\circ} \mathrm{C}$ in the same buffer containing $3.1 \mathrm{~mm}$ potassium ferricyanide, $3.1 \mathrm{~mm}$ potassium ferrocyanide, $1 \mathrm{mM} \mathrm{MgCl}$, and $0.4 \mathrm{mg} / \mathrm{ml}$ of Bluo-gal (BRL). A blue reaction product precipitates in the tissue in the presence of $\beta$-galactosidase activity. After the staining reaction, the $1-\mathrm{mm}$-thick brain sections were incubated overnight in $30 \%$ sucrose in $0.1 \mathrm{M}$ phosphate buffer $(\mathrm{pH} 7.5)$, frozen at $-40^{\circ} \mathrm{C}$, and mounted on a freezing microtome, and $30-\mu \mathrm{m}-$ thick sections were obtained. The spinal cord samples were embedded in O.C.T. compound (Tissue Tek, Miles) and frozen at $-40^{\circ} \mathrm{C}$, and $10-\mu \mathrm{m}$-thick sections were obtained using a cryostat (Leitz 1720 Digital). Vibratome sections were mounted on glass slides and viewed without further processing. Microtome and cryostat sections were mounted on gelatinized slides, counterstained with pyronin $\mathrm{Y}$, and dehydrated with acetone and xylenes. Eyes were cut into two pieces, and the lenses were removed. The retina was embedded in epon, and 1- to $2-\mathrm{mm}$ cross sections were cut with an ultramicrotome and counterstained with pyronin $Y$.

To determine the developmental expression profile of $\beta$-galactosidase activity, hemizygous transgenic mice were time-mated with B6C3F1 or B6C3F2 mice (plug date $=$ E0). To provide age-matched controls, both the transgenic and normal littermates were analyzed. Embryos from day 8 to day 11 (E8E11) were immersion-fixed for $45 \mathrm{~min}$. Embryos from E12 to E16 were immersion-fixed for $10 \mathrm{~min}$, cut in half longitudinally, and fixed for an additional $45 \mathrm{~min}$. From E16 to P15, fetuses or pups were anesthetized by cooling on ice for $15 \mathrm{~min}$ or with avertin IP and fixed by transcardiac perfusion $(10 \mathrm{ml})$, and the dissected tissues were postfixed for an additional $45 \mathrm{~min}$, rinsed in phosphate buffer, and incubated in stain overnight.

\section{Acknowledgments}

We gratefully acknowledge the assistance of S. Albrechtson, D. Barber, S. Gauthier, A. Karparti, J. Tremblay, and P. Valera. We thank Drs. A. Beaudet, R. Campbell, M. Park, and C. Sapienza for helpful discussions and advice. S.V. is a Ludwig Institute Postdoctoral Fellow. Parts of this work were supported by the Ludwig Institute (A.C.P.) and by National Institutes of Health grant NS 22920 (H.T.O.).

The publication costs of this article were defrayed in part by payment of page charges. This article must therefore be hereby marked "advertisement" in accordance with 18 USC section 1734 solely to indicate this fact.

\section{References}

Al-Shawi, R., J. Kinnaird, J. Burke, and J.O. Bishop. 1990. Expression of a foreign gene in a line of transgenic mice is modulated by a chromosomal position effect. Mol. Cell Biol. 10: 1192-1198.

Altman, J. 1972. Postnatal development of the cerebellar cortex in the rat. II. Phases in the maturation of the Purkinje cells and of the molecular layer. I. Comp. Neurol. 145: 399-464.

Angel, P., M. Imagawa, R. Chiu, B. Stein, R.J. Imbra, H.J. Rahmsdorf, C. Jonat, P. Herrlich, and M. Karin. 1987. Phorbol-ester inducible genes contain a common cis-element recognized by a TPA modulated trans-acting factor. Cell 49: 729-739.

Ayer, S. and C. Benyajati. 1990. Conserved enhancer and silencer elements responsible for differential $A d h$ transcription in Drosophila cell lines. Mol. Cell. Biol. 10: 3512-3523.

Baniahmad, A., M. Muller, C. Steiner, and R. Renkawitz. 1987. Activity of two different silencer elements of the chicken lysozyme gene can be compensated by enhancer elements. $E M B O$ I. 6: 2297-2303 .

Baniahmad, A., C. Steiner, A.C. Köhne, and R. Renkawitz, 1990. Modular structure of a chicken lysozyme silencer: Involvement of an unusual thyroid hormone receptor binding site. Cell 61: 505-514.

Barber, R.P. and J.E. Vaughn. 1986. Differentiation of dorsal root ganlion cells with processes in their synaptic target zone of embryonic mouse spinal cord: A retrograde tracer study. $I$. Neurocytol. 15: 207-218.

Baumruker, T., R. Sturm, and W. Herr. 1988. OBP100 binds remarkably degenerate motifs through specific interactions with flanking sequnces. Genes \& Dev. 2: 1400-1413.

Berg, P.E, D.M. Williams, R.L. Qian, R.B. Cohen, S.X. Cao, M. Mittelman, and A.N. Schechter. 1989. A common protein binds to two silencers $5^{\prime}$ to the human $\beta$-globin gene. $\mathrm{Nu}$ cleic Acids Res. 17: 8833-8852 .

Boegman, R.J., A. Parent, and R. Hawkes. 1988. Zonation in the rat cerebellar cortex: Patches of high acetylcholinesterase activity in the granular layer are congruent with Purkinje cells compartment. Brain Res. 448: 237-251.

Bonnerot, C., G. Grimber, P. Briand, and J.F. Nicolas. 1990. Patterns of expression of position-dependent integrated transgenes in mouse embryo. Proc. Natl. Acad. Sci. 87: 6331-6335.

Bouvagnet, P., E.E. Strehler, G. White, M.A. Strehler-Page, B. Nadal-Ginard, and V. Mahdavi. 1987. Multiple positive and 
negative $5^{\prime}$ regulatory elements control the cell-type-specific expression of the embryonic skeletal myosin heavy-chain gene. Mol. Cell Biol. 7: 4377-4389 .

Brand, A.H., L. Breeden, J. Abraham, R. Sternglanz, and K. Nasmyth. 1985. Characterization of a "silencer" in yeast: A DNA sequence with properties opposite to those of a transcriptional enhancer. Cell 42: 42-48 .

Brochu, G., L. Maler, and R. Hawkes. 1990. Zebrin II a polypeptide antigen expressed selectively by Purkinje cells reveals compartments in rat and fish cerebellum. J. Comp. Neurol 291: $538-552$.

Burt, D.W., N. Nakamura, P. Kelley, and V.J. Dzau. 1989. Identification of negative and positive regulatory elements in the human renin gene. I. Biol. Chem. 264: 7357-7362 .

Byrne, G.W. and F.H. Ruddle. 1989. Multiplex gene regulation: A two-tiered approach to transgene regulation in transgenic mice. Proc. Natl. Acad Sci. 86: 5473-5477.

Cao, S.X., P.D Gutman, H.P.G Dave, and A.N. Schechter. 1989. Identification of a transcriptional silencer in the $5^{\prime}$-flanking region of the human $\epsilon$-globin gene. Proc. Natl. Acad. Sci. 86: 5306-5309.

Covarrubias, L., Y. Nishida, M. Terao, P. D'Eustachio, and B. Mintz. 1987. Cellular DNA rearrangements and early developmental arrest caused by DNA insertion in transgenic mouse embryo. Mol. Cell Biol. 7: 2243-2247.

Davies, A.M. and A. Lumsden. 1984. Relation of target encounter and neuronal death to nerve growth factor responsiveness in the developing mouse trigeminal ganglion. I. Comp. Neurol. 223: 124-137.

Edwards M.A., V.S. Caviness, and G.E. Schneider. 1986. Development of cell and fiber lamination in the mouse superior colliculus. I. Comp. Neurol. 248: 395-409.

Eisenman, L.M. and R. Hawkes. 1989. $5^{\prime}$-Nucleotidase and the MabQ113 antigen share a common distribution in the cerebellar cortex of the mouse. Neuroscience 31: 231-235.

Emerson, B.M., J.M. Nickol, and T.C. Fong. 1989. Erythroidspecific activation and derepression of the chick $\beta$-globin promoter in vitro. Cell 57: 1189-1200 .

Farrell, F.X., C.M. Sax, and Z.E. Zehner. 1990. A negative element involved in vimentin gene expression. Mol. Cell Biol. 10: 2349-2358.

Fjorss-Petter, S., P.E. Danielson, S. Catsicas, E. Battenberg, J. Price, M. Nerenberg, and J.G. Sutcliffe. 1990. Transgenic mice expressing $\beta$-galactosidase in mature neurons under neuron-specific enolase promoter control. Neuron 5: 187197.

Fujita, T., C. Takaoka, H. Matsui, and T. Taniguchi. 1983. Structure of the human interleukin gene. Proc. Natl. Acad. Sci. 80: 7437-7441.

Gravel, C., L.M. Eisenman, R. Sasseville, and R. Hawkes. 1987. Parasagittal organization of the rat cerebellar cortex: Direct correlation between antigenic Purkinje cell band revealed by mabQ113 and the organization of the olivocerebellar projection. J. Comp. Neurol. 265: 294-310.

Habener, J.F., B.J. Cwikel, H. Hermannn, R.E. Hammer, R.D. Palmiter, and R.L. Brinster. 1989. Metallothionein-vasopressin fusion gene expression in transgenic mice. J. Biol. Chem. 264: 18844-18852.

He, X., M.N. Treacy, D.M. Simmon, H.A. Ingraham, L.W. Swanson, and M.G. Rosenfeld. 1989. Expression of a large family of POU domain regulatory genes in mammalian brain development. Nature 340: 35-42.

Herbst, R.S., N. Friedman, J.E. Darnell Jr, and L.E. Babiss. 1989. Positive and negative regulatory elements in the mouse albumin enhancer. Proc. Natl. Acad. Sci. 86: 1553-1557 .

Herrup, K. and S.L. Wilczynsky. 1982. Cerebellar cell degener- ation in the leaner mutant mouse. Neuroscience 7: 21852196.

Hogan, B., F. Constantini, and E. Lacy. 1986. Manipulating the mouse embryo. A laboratory manual. Cold Spring Harbor Laboratory, Cold Spring Harbor Laboratory New York.

Hyman, S.E., M. Comb, Y.S. Lin, J. Pearlberg, M.R. Green, and H.M. Goodman. 1988. A common trans-acting factor is involved in transcriptional regulation of neurotransmitter genes by cyclic AMP. Mol. Cell Biol. 8: 4225-4233.

Imler, J.L., C. Lemaire, C. Wasylyk, and B. Wasylyk. 1987. Negative regulation contributes to tissue-specificity of the immunoglobulin heavy-chain enhancer. Mol. Cell Biol. 7: 2558-2567.

Johnson, W.A., C.A. McCormick, S.J. Bray, and J. Hirsch. 1989. A novel neuron-specific enhancer of the Drosophila dopa decarboxylase gene. Genes \& Dev. 3: 676-686.

Julien, J.-P., 1. Tretjakoff, L. Beaudet, and A. Peterson. 1987. Expression and assembly of a human neurofilament protein in transgenic mice provide a novel neuronal marking system. Genes \& Dev. 1: 1085-1095.

Kislauskis E. and P.R. Dobner. 1990. Mutually dependent response elements in the cis-regulatory region of the neurotensin/ neuromedin $\mathrm{N}$ gene integrate environmental stimuli in PC12 cells. Neuron 4: 783-795.

Korner, M., A. Rattner, F. Mauxion, R. Sen, and Y. Citri. 1989. A brain-specific transcription activator. Neuron 3: 563-572.

Kozak, M. 1984. Compilation and analysis of sequences upstream from the translational start site in eukaryotic mRNAs. Nucleic Acids Res. 12: 857-872.

Kuhl, D., J. de la Fuente, M. Chaturvedi, S. Parimoo, J. Ryals, F. Meyer, and C. Weissman. 1987. Reversible silencing of enhancers by sequences derived from the human IFN- $\alpha$ promoter. Cell 50: 1057-1069.

Laimins, L., M. Holmgren-König, and G. Khoury. 1986. Transcriptional "silencer" element in rat repetitive sequences associated with the rat insulin 1 gene locus. Proc. Natl. Acad. Sci. 83: 3151-3155.

Leclerc, N., C. Gravel, and R. Hawkes. 1988. The development of the parasagittal zonation in the rat cerebellar cortex. MabQ1 13 antigenic bands are created postnatally by the suppression of antigen expression in a subset of Purkinje cells. J. Comp. Neurol. 273: 399-420.

Locker, J. and G. Buzard. 1990. A dictionary of transcription control sequences. J. DNA Sequencing Mapping 1: 3-11.

Mahon, K.A., P.A. Overbeek, and H. Westphal. 1988. Prenatal lethality in a transgenic mouse line is the result of a chromosomal translocation. Proc. Natl. Acad. Sci. 85: 11651168.

Maniatis, T., E.F. Fritsch, and J. Sambrook. 1982. Molecular cloning: A laboratory manual. Cold Spring Harbor Laboratory, Cold Spring Harbor, New York.

Maniatis, T., S. Goodbourn, and J.A. Fischer. 1987. Regulation of inducible and tissue-specific gene expression. Science 236: $1237-1245$.

Mathey-Prevot, B., N.C. Andrews, H.S. Murphy, S.G. Kreissman, and D.G Nathan. 1990. Positive and negative elements regulate human interleukin 3 expression. Proc. Natl. Acad. Sci. 87: 5046-5050 .

Maue, R.A., S.D. Kraner, R.H. Goodman, and G. Mandel. 1990. Neuron-specific expression of the rat brain type II sodium channel. Neuron 4: 223-231.

McGowan, R., R. Campbell, A. Peterson, and C. Sapienza. 1989. Cellular mosaicism in the methylation and expression of hemizygous loci in the mouse. Genes \& Dev. 3: 1669-1676.

Metcalf, D., and J.G. Moore. 1988. Divergent disease patterns in granulocyte-macrophage colony-stimulating factor trans- 
genic mice associated with different transgene insertion sites. Proc. Natl. Acad. Sci. 85: 7767-7771.

Miale, I.L. and R.L. Sidman. 1961. An autoradiographic analysis of histogenesis in the mouse cerebellum. Exp. Neurol. 4: 277-296.

Mori N., R. Stein, O. Sigmund, and D.J. Anderson. 1990. A cell type-preferred silencer element that controls the neural-specific expression of the SCG10 gene. Neuron 4: 583-594.

Myers, R.M, K. Tilly, and T. Maniatis. 1986. Fine structure genetic analysis of a $\beta$-globin promoter. Science 232: 613618.

Myers, M.W., R.A. Lazzarini, V.M.-Y. Lee, W.W. Schlaepfer and D.L. Nelson. 1987. The human mid-size neurofilament subunit: A repeated protein sequence and the relationship of its gene to the intermediate filament gene family. $E M B O \mathrm{~J}$. 6: 1617-1626.

Nakahira, K., K. Ikenaka, K. Wada, T. Tamura, T. Furuich, and K. Mikoshiba. 1990. Structure of the $68 \mathrm{kD}$ neurofilament gene and regulation of its expression. I. Biol. Chem. 32: 19786-19791.

Nir, U., M.D. Walker, and W. Rutter. 1986. Regulation of rat insulin 1 gene expression: Evidence for negative regulation in nonpancreatic cells. Proc. Natl. Acad. Sci. 83: 3180-3184.

Nordquist, D.T., C.A. Kozak, and H.T. Orr. 1988. cDNA cloning and characterization of three genes uniquely expressed in cerebellum by Purkinje cells. I. Neurosci. 8: 4780-4789.

Oberdick, J., F. Levinthal, and C. Levinthal. 1988. A Purkinje cell differentiation marker shows a partial DNA sequence homology to the cellular sis/PDGF2 gene. Neuron 1:367376 (Erratum. 3: 385).

Oberdick, J., R.J. Smeyne, J.R. Mann, S. Zackson, and J.I. Morgan. 1990. A promoter that drives transgene expression in cerebellar Purkinje and retinal bipolar neurons. Science 248: 223-226.

O'Neill, E.A., C. Fletcher, C.R. Burrow, N. Heintz, R. Roeder, and T.J. Kelly. 1988. Transcription factor OTF-1 is functionally identical to the DNA replication factor NFIII. Science 241: $1210-1213$.

Osborne, T.F., G. Gil, J.L. Goldstein, and M.S. Brown. 1988. Operator constitutive mutation of 3-hydroxy-3-methylglutaryl coenzyme A reductase promoter abolishes protein binding to sterol regulatory element. I. Biol. Chem. 263: 3380-3387.

Quinn, P.G., T.W. Wong, M.A. Magnuson, J.B. Shabb, and D.K. Granner. 1988. Identification of basal and cyclic AMP regulatory elements in the promoter of the phosphoenolpyruvate carboxykinase gene. Mol. Cell Biol. 8: 3467-3475.

Rosen, H., J. Douglas, and E. Herbert. 1984. Isolation and characterization of the rat proenkephalin gene. I. Biol. Chem. 259: 14309-14313.

Ross, M.E., C. Fletcher, C.A. Mason, M.E. Hatten, and N. Heintz. 1990. Meander tail reveals a discrete developmental unit in the mouse cerebellum. Proc. Natl. Acad. Sci. 87: 4189-4192

Sakimura, K., E. Kushiya, Y. Takahashi, and Y. Suzuki. 1987. The structure and expression of neuron-specific enolase. Gene 60: 103-113.

Salier, J.P., S. Hirosawa, and K. Kurachi. 1990. Functional characterization of the $5^{\prime}$-regulatory region of human factor IX gene. J. Biol. Chem. 265: 7062-7068.

Sanger, F., S. Nicklen, and A.R. Coulson. 1977. DNA sequencing with chain-terminating inhibitors. Proc. Natl. Acad. Sci. 74: 5463-5470.

Savagner, P., T. Miyashita, and Y. Yamada. 1990. Two silencers regulate the tissue-specific expression of the collagen II gene. I. Biol. Chem. 265: 6669-6674.
Schöler, H.R., A.K. Hatzopoulos, R. Balling N. Suzuki, and P. Gruss. 1989a. A family of octamer-specific proteins present during mouse embryogenesis: Evidence for germline-specific expression of an Oct factor. $E M B O$ J. 8: 25512557.

Schöler, H.R., R. Balling, A.K. Hatzopoulos, N. Suzuki, and P. Gruss. 1989b. Octamer binding proteins confer transcriptional activity in early mouse embryogenesis. $E M B O \quad J$. 8: 2551-2557.

Scholnick, S.B., S.J. Bray, B.A. Morgan, C.A. McCormick, and J. Hirsch. 1986. CNS and hypoderm regulatory elements of the Drosophila melanogaster dopa decarboxylase gene. Science 234: 998-102.

Sen, R. and D. Baltimore. 1986a. Multiple nuclear factors interact with the immunoglobulin enhancers sequences. Cell 46: 705-715.

1986b. Inducibility of $\kappa$ immunoglobulin enhancerbinding protein NF- $\mathrm{kB}$ by a post-translational mechanism. Cell 47: 921-928.

Sheng, M. and M.E. Greenberg. 1990. The regulation and function of c-fos and other immediate early genes in the nervous system. Neuron 4: 477-485.

Sidman, R.L., J.B. Angevine, Jr. and E. Taber Pierce. 1971. Atlas of the mouse brain and spinal cord. Harvard University Press, Cambridge, MA.

Slotnick B.M. and C.M. Leonard. 1975. A stereotaxic atlas of the albino mouse forebrain. U.S. Public Health Service, Rockville, MD.

Suzuki, N., H. Rohdewold, T. Neuman, P. Gruss, and H.R. Schöler. 1990. Oct-6: A POU transcription factor expressed in embryonal stem cells and in the developing brain. EMBO I. 9: 3723-3732.

Swanson L.W., D.M. Simmons, J. Arriza, R. Hammer, R. Brinster, M.G. Rosenfeld, and R.M. Evans. 1985. Novel developmental specificity in the nervous system of transgenic animals expressing growth fusion genes. Nature 317: 363-366.

Theiler, K. 1972. The house mouse. Development and normal stages from fertilization to 4 weeks of age. Springer-Verlag, Berlin/Heidelberg/New York.

Thompson M.A. and E.B. Ziff. 1989. Structure of the gene encoding peripherin, and NGF-regulated neuronal-specific type III intermediate filament protein. Neuron 2: 1043-1053.

Tuggle, C.K., J.Zakany, L. Cianetti, C. Peschle, and M.C. Nguyen-Huu. 1990. Region-specific enhancers near two mammalian homeo box genes define adjacent rostraucaudal domains in the central nervous system. Genes \& Dev. 4: 180-189.

Vieira, J., and J. Messing. 1982. The PUC plasmids and M13 MP-7 derived system for insertion mutagenesis and sequencing with synthetic universal primers. Gene 19: 259268.

Wassef, M., J.P. Zanetta, A. Brehier, and C. Sotelo. 1985. Transient biochemical compartmentalization of Purkinje cells during early cerebellar development. Dev. Biol. 111: 129137.

Wassef, M., C. Sotelo, M. Thomasset, A.C. Granholm, N. Leclerc, J. Rafrafi, and R. Hawkes. 1990. Expression of compartmentation antigen zebrin $\mathrm{I}$ in cerebellar transplants. $I$. Comp. Neurol. 294: 223-234.

Winoto, A. and D. Baltimore. 1989. $\alpha \beta$ lineage-specific expression of the $\mathrm{T}$ cell receptor gene by nearby silencers. Cell 59: 649-655.

Wuenschell, C.W., N. Mori, and D.J. Anderson. 1990. Analysis of SCG10 expression in transgenic mice reveals that neural specificity is achieved through selective derepression. Neuron 4: 595-602. 


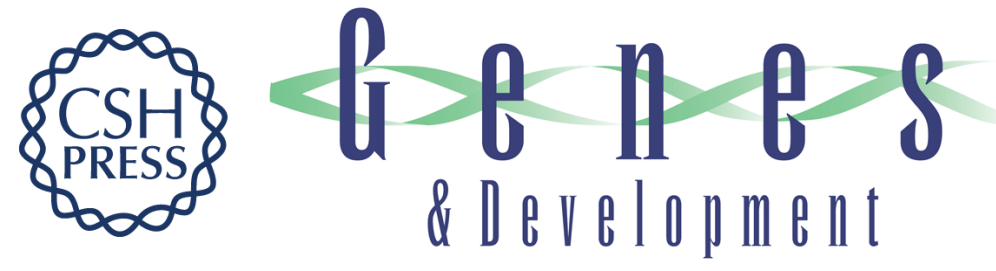

\section{Purkinje cell protein-2 regulatory regions and transgene expression in cerebellar compartments.}

S Vandaele, D T Nordquist, R M Feddersen, et al.

Genes Dev. 1991, 5:

Access the most recent version at doi:10.1101/gad.5.7.1136

References This article cites 79 articles, 36 of which can be accessed free at: http://genesdev.cshlp.org/content/5/7/1136.full.html\#ref-list-1

License

Email Alerting

Service

Receive free email alerts when new articles cite this article - sign up in the box at the top right corner of the article or click here.

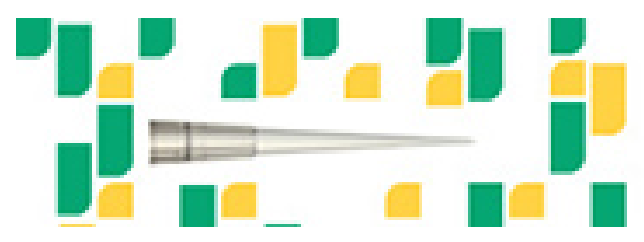

Focused on your science.

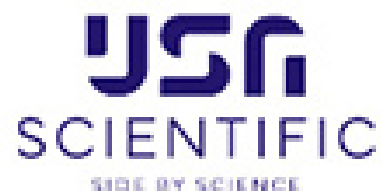

Copyright @ Cold Spring Harbor Laboratory Press 